\title{
Jhumpa Lahiri: Inspiring Assimilation of Cultures in The Namesake
}

\author{
Dr. Neeta Pandey \\ Assistant Professor in the Department of English GD Rungta College of Engineering and Technology \\ Kohka-Kurud Road Bhilai
}

\begin{abstract}
Jhumpa Lahiri in her book The Namesake, now a major motion picture, unfolds the lives of Indians and Indian Americans struggling for adoption and assimilation of cultures. She displays the soul of the characters experiencing displacement, guilt, and fear, who are perplexed to balance their own tradition and culture with the new culture. They are at the crossroads of culture struggling hard to assimilate the cultures. No doubt, Jhumpa accepts that she has taken some bits and pieces of her stories from her own parents and even others, whom she knew growing up, she also admits that sometimes they are totally invented. In her interview with Bookforum, she confesses that:

The thing I took for granted when I was growing up is that I was living in a world within a world. It was a tight world, but I knew a lot of people and was privy to the whole spectrum of types and personalities and characters. To me, they don't represent immigrants or any one specific. They just represent the human condition (Migration, Assimilation, and Inebriation).
\end{abstract}

In The Namesake, Lahiri has presented the issue of names and identity. She has depicted the Bengali culture in which the children are given two names: one that is pet name, used by family and friends, and one that is used in society. At birth, the main protagonist--Gogol is given a pet name, which becomes his official name as well, because the name sent by his grandmother gets lost in the mail. The decision to retain his pet name for 'namesake' causes years of distress to Gogol, as he realizes his differences with the Americans. When he leaves for college, he rejects his identity and becomes Nikhil(the name which he rejected in childhood). Gogol realizes quite late that identity is more important than the name, and that he should have been more concerned with finding his identity, than bothering for name.

Article: Jhumpa Lahiri, in his novel--The Namesake, shows isolation in the life of the protagonists--Ashima and Ashoke Ganguli, who immigrated to America from India in quest of their own identity. Ashoke has been depicted as a doctoral candidate in Electrical Engineering at MIT-Massachusetts Institute of Technology, and Ashima as a house-wife. At the mount Auburn Hospital, when Ashima finds herself deserted, she is unable to interact with others, as she has gathered that American women are different from Indian. Though eighteen months had passed, Ashima could not adjust herself in Cambridge. She could feel that though the Americans make public declarations of their affection openly, wear miniskirts and bikinis; they prefer their privacy. Now she was at the hospital for delivery, but she experiences something else, other than the pain of pregnancy. She is terrified to raise a child in a country where she is related to no one, where she knows so little about the people and their culture. She wonders if she would have been in India with her loved ones, she would have got their support and blessings.

A turning point came in the life of Ashoke, when he was twenty two, a student at B.E. College. He was travelling on the 83 Up Howrah-Ranchi Express to visit his grandparents for the holidays, when he experienced something which changed his life as well as the course of life of his son--Gogol. His train met with an accident which killed the first-class and air-conditioned passengers in their sleep. The seventh compartment where Ashoke was there, had capsized as well, which made him experience as if he was born twice in India. For Ashoke, it was an encounter with death. He had broken his pelvis, his right femur, and three of his ribs on the right side. For more than a year, he lay flat on his bed and it was then that he decided to go to America. He had developed a love for the book and its author Nikolai Gogol whose single page of "the overcoat", the last story of the book, he held in hand, when he was pulled from the wreckage. He could realize that it was because of the author Gogol, he had got a second life in India. This made him Christian his sonGogol, in the name of the Russian writer, who he felt had saved his life. Though Ashoke had tried a lot to get rid of the nightmares, even after seven years of his residing in America, he could not get rid of his horrifying experience:

At every turning point in his life--at his wedding when he stood behind Ashima, encircling her waist and peering over her shoulder as they poured puffed rice into a fire, or during his first hours in America, seeing a small gray city caked with snow--he has tried but failed to push these images away: the twisted, battered, 
capsized bogies of the train, his body twisted below it, the terrible crunching sound he had heard but not comprehended, his bones crushed as fine as flour (Lahiri, 21).

For Ashoke, the rescue from the mishap was a miracle. And another miracle was the birth of his child, for naming whom, they had asked Ashima's grandmother to do the honours. The letter could not reach them before leaving the hospital, so for the sake of birth certificate Ashoke names him Gogol--the name that stood for his own life. Just like Ghosh who had come back from England for his wife's sake, Ashima also wanted to came back to India as she missed her parents a lot. She even realizes that lack of amenities like sweeping the floor, or doing the dishes, was the American way of life. The hustle-bustle of the hospital, at the time of delivery, was acceptable to Ashima, rather than the gloomy three-room apartment. In every letter which she wrote to her mother, she described about Gogol--about his first smile, the day he rolls over, and his first squeal of delight. The vacuum in the lives of Indian women has been reflected by Lahiri in the titles 'homesick' and 'bewildered', which she has used for wives, who passed their time singing songs, discussing recipes, films, and politics. On the occasion of Gogol's annaprasan--his rice ceremony, Ashima is unable to control her emotions:

Ashima's eyes fill with tears as Gogol's mouth eagerly invites the spoon. She can't help wishing her own brother were here to feed him, her own parents to bless him with their hands on his head (Lahiri, 40).

Lahiri depicts the loneliness and isolation in the lives of foreigners by depicting the critical situations. Even when one loses someone who is very close to him, one is unable to show one's sentiments to others in the closing years of his life. When Ashima's father passed away, she could leave for India six days later, with no hope of meeting him again. Lahiri feels that the world narrows down for the foreigners, as they are unable to think or do anything beyond it. It was not Ashima alone, who felt nostalgic about India, but so many other Indian women who forced their husbands to return to their own homeland:

For being a foreigner, Ashima is beginning to realize, is a sort of lifelong pregnancy-- a perpetual wait, a constant burden, a continuous feeling out of sorts. It is an ongoing responsibility, a parenthesis in what had once been ordinary life, only to discover that previous life has vanished, replaced by something more complicated and demanding. Like pregnancy, being a foreigner, Ashima believes, is something that elicits the same curiosity from strangers, the same combination of pity and respect (Lahiri, 49-50).

Lahiri exhibits the parents' anxiety in retention of their own culture. Ashima and Ashoke loved watching their son eat with his fingers as per the Bengali culture. They even had the fear that after them, he may not do so. Gogol, while going to kindergarten became unhappy at the thought of being called 'Nikhil'--someone he does not know. That is the reason he remains Gogol at kindergarten as well. But he does not realize that it is the name 'Gogol', which he got as Namasake, will make him feel embarrassed throughout his life. Though he realizes quite late that it is not the name, but one's identity, by which one is known in life. Gogol and his sisterwho was five years older than him, considered themselves Americans as they were born in this land. They looked forward more to Christmas celebrations, than to the worship of Durga and Saraswati. But Ashima and Ashoke tried their best to make them acquainted with the Bengali culture. In third grade, they sent Gogol to Bengali language and culture lessons every other Saturday. On Gogol's fourteenth birthday, his father presented him 'the short stories of 'Nikolai Gogol', his favourite Russian author. But Gogol never became interested in reading a word of Gogol, being unaware of the accident that had nearly killed his father, and which gave him his name. That was the reason Gogol had developed hatred for his name:

For by now, he's come to hate questions pertaining to his name, hates having constantly to explain. He hates having to tell people that it does not mean anything "in Indian". He hates having to wear a nametag on his sweater at Model United Nations Day at school. He even hates signing his name at the bottom of his drawings in art class. He hates that his name is both absurd and obscure, that it has nothing to do with who he is, that is is neither Indian nor American but of all things Russian. He hates having to live with it, with a pet name turned good name, day after day, second after second (Lahiri, 75-76).

The name "Gogol" distressed him physically as well. He found his name shapeless and weightless, and he could not imagine girls calling him "Gogol" under romantic circumstances. He suppressed his emotions, and here he made a mistake. If he would have insisted his father to know the real reason behind his name, 'he' would have possibly got a convincing answer. But he kept silent, suffering alone, bringing disaster to prime years of his life. Gogol feels that he has no identity, as his name lacked dignity or gravity. His suffering intensifies when he thinks that:

Not only does Gogol Ganguli have a pet name turned good name, but a last name turned first name. And so it occurs to him that no one he knows in the world, in Russia or India or America or anywhere, shares his name. Not even the source of his namesake (Lahiri, 78). 
A visit to India for eight months by Gogol's family seems to Gogol as cumbersome, having no relevance to their lives. He was now American--loved American culture and American life. The name "Gogol" was torturing him like anything, and when he hears an account of Nikolai Gogol's biography, it worsens his condition. Mr. Lawson, Gogol's teacher, describes Nikolai Gogol-- the author, as an intelligent, queer, and sickly creature. He also reputed him to be a hypochondriac and a deeply paranoid, frustrated man, who never married, fathered no children. Each time Mr. Lawson uttered Nikolai Gogol's name, Gogol quietly winced and experienced the pain. Whenever he listened to his classmates' complain, he felt as if his own work was being attacked. Gogol's dislike for his own name brought misery to his life. He did not date with anyone in high school; did not attend dances, and did not listen to the records together. Gogol was unlike American teenagers, that is the reason, his parents were not anxious of his career. But the new name Nikhil brought him disaster:

It is as Nikhil, that first semester, that he grows a goatee, starts smoking Camel Lights at parties and while writing papers and before exams, discovers Brian Eno and Elvis Costello and Charlie Parker. It is as Nikhil that he takes Metro-North into Manhattan one weekend with Jonathan and gets himself a fake ID that allows him to be served liquor in New Haven bars. It is as Nikhil that he loses his virginity at a party at Ezra Stiles.... (Lahiri, 105).

Gogol had never seen his father expressing his thoughts, desires, and moods on any of the occasions. On one windy night, the revelation of the truth about his name comes as a shock to Gogol. He is stunned to know about his father's past who had survived a tragedy and had suffered in an inconceivable way:

He imagines his father, in his twenties as Gogol is now, sitting on a train as Gogol had just been, reading a story, and then suddenly nearly killed. He struggles to picture the West Bengal countryside he has seen on only a few occasions, his father's mangled body, among hundreds of dead ones, being carried on a stretcher, past a twisted length of maroon compartments(Lahiri,123).

Like Ashoke and Ashima Ganguli; Gogol and Sonia struggle to respect their culture, while adapting to American society. Gogol had changed with the new culture in New York, and an isolation had come into his life. Though he got support of his parents, he had become detached from them. It seemed that now he had no sentiments for them:

...after four years in New Haven he didn't want to move back to Massachusetts, to the one city in America his parents know. He didn't want to attend his father's almamater, and live in an apartment in Central Square as his parents once had, and revisit the streets about which his parents speak nostalgically. He didn't want to go home on the weekends, to go with them to pujos and Bengali parties, to remain unquestionably in their world (Lahiri, 126).

Gogol finds quite comfortable to get incorporated into the lives of Ratliffs family. He is enraptured by Maxine's pale green-gray eyes, and finds interest in talking to her parents Gerald and Lydia. He is too much influenced by their brand of hospitality, so much that he loses his own identity He forgets his own country, his own culture, and his own parents:

Quickly, simultaneously, he falls in love with Maxine, the house, and Gerald and Lydia's manner of living, for to know her and love her is to know and love all of these things. He loves the mess that surrounds Maxine.....He learns to love the food she and her parents eat....He learns that one does not grate Parmesan cheese over pasta dishes containing seafood. He learns not to put wooden spoons in the dishwasher....The nights he spends there, he learns to wake up earlier than he is used to....He learns to anticipate, every evening the sound of a cork emerging from a fresh bottle of wine (Lahiri, 137).

In contrast to Maxine, who shows all respect to her parents' tastes and ways of life, Gogol feels no exasperation for his own parents, no sense of obligation. He could imagine the differences in Maxine's parents way of living, and his own. He could find only a dozen of guests invited to dinner at Maxine's house. Whereas at his parents' parties, he could see not fewer than thirty people invited, where his parents behaved more like caterers in their own home, watchful and waiting until most of the guests' plates were stacked by the sink. Though he knew that there was a wide difference in culture of his parents and Maxine's parents, he could not remain uninfluenced by the foreign culture:

He cannot imagine his parents sitting at Lydia and Gerald's table, enjoying Lydia's cooking, appreciating Gerald's selection of wine. He cannot imagine them contributing to one of their dinner party conversations. And yet here he is, night after night, a welcome addition to the Ratliff's universe, doing just that (Lahiri, 141).

Gogol becomes insensitive to his parents' desires. Inspite of his mothers' request to visit Massachusetts to see off his father to the airport who was going for a research work to Ohio for nine months; Gogol prefers going to New Hampshire with Maxine for two weeks. Though Gogol takes Maxine to his parents' house, he is unable to appreciate their noble gestures. His mother had prepared meals, which had taken more than a day, yet he feels embarrassed by the effort she had put in for it. Gogol feels relieved in the world of Maxine, in contrast to the world of his parents, where he felt uneasy and uncomfortable: 
He feels no nostalgia for the vacations he's spent with his family, and he realizes now that they were never really true vacations at all. Instead they were overwhelming, disorienting expeditions, either going to Calcutta, or sightseeing in places they did not belong to and intended never to see again (Lahiri, 155).

Another turning point comes in the life of Gogol, when his father expires. He feels the guilt and realizes the sentiments for him, looking at the left out things in his flat at Cleveland. A significant change comes in Gogol's life after the permanent absence of his father. He becomes indifferent to Maxine which leads to their breakup:

At first she'd been patient with him, and for a while he'd allowed himself to fall back into her life, going home after work to her parents' house, to their world in which nothing had changed. Initially she'd tolerated his silences at the dinner table, his indifference in bed, his need to speak to his mother and Sonia every evening, and to visit them, on weekends, without her (Lahiri, 188).

After Maxine, it was Moushumi Mazoomdar, with whom Nikhil goes on a blind date, who was the daughter of friends of his parents. Then he comes to know about her life, about her prenuptial disaster. He gets attracted to her, inspite of knowing the fact that in the past she had allowed men to seduce her in cafe's, in parks, and many other places. Though Gogol knew that there were days she slept with one man after lunch, another after dinner, Gogol marries Moushimi within a year. After their first marriage anniversary, Moushimi happens to meet Dimitri Desjardins, whom she had met years ago, in her final months of high school. Moushumi still remembers how on their first date, he had treated her like a child. And how he used to send her postcards and books while she was at Brown. Moushumi develops infatuation, and starts meeting Dimitri every Monday and Wednesday, inspite of having the guilt that she had betrayed her husband.

Lahiri depicts the desolation in the lives of Indians who settle abroad. She has depicted the lives of those who dwell abroad, leaving their respective family behind, and remain in a perpetual state of expectation and longing. Gogol realizes how his parents had lived their lives in America, inspite of what was missing. And making few trips to Calcutta would not have been enough for them to stay out of those perpetual fears, same way, Gogol had spent years maintaining distances from his parents. Just like a bird who returns to one's nest, Lahiri feels that finally one returns to one's own country. Ashima, now a widow, wanted to go back to India for few months.

Gogol wanted to correct his name--the first thing given by his father name. But he could not correct his life, his life was a failure and his marriage was a misstep. The name had distressed him for years, which he could change, but he could not change the things which happened in his life, which prevailed, and which he endured till the end. And now when he realizes the significance of the name given by his father, and longs to be called "Gogol", there is no one to call him by this name. His father is no more alive, and his mother-a widow who is shifting to India, would call him "Gogol" only once a week. The name which Gogol always despised, the name which he always hated, now would vanish. Nikhil had won over Gogol, but it did not give happiness to him. He realizes quite late that more than a name, a man's identity is important:

Without people in the world to call him Gogol, no matter how long he himself lives, Gogol Ganguli will, once and for all, vanish from the lips of loved ones and so, cease to exist. Yet the thought of this eventual demise provides no sense of victory, no solace. It provides no solace at all (Lahiri, 289).

\section{List of References}

[1] Dubey, Ashutosh. "Immigrant Experience in Jhumpa Lahiri's Interpreter of Maladies."

[2] Journal of Indian Writing in English 30.2(2002):22-6.

[3] Lahiri, Jhumpa. The Namesake. India: HarperCollins,2003.

--- Ibid.

--- Ibid.

---,Ibid.

---Ibid.

---Ibid.

---Ibid.

---Ibid.

---Ibid.

---Ibid.

---Ibid.

---Ibid.

---Ibid. 